\title{
Anabases
}

ANABASES Traditions et réceptions de l'Antiquité

26 | 2017

Varia

\section{Revisiting the upper floors of the Casa d'Argo at Herculaneum*}

James N. Andrews

\section{(2) OpenEdition}

1 Journals

Electronic version

URL: http://journals.openedition.org/anabases/6326

DOI: 10.4000/anabases.6326

ISSN: 2256-9421

Publisher

E.R.A.S.M.E.

\section{Printed version}

Date of publication: 1 November 2017

Number of pages: 117-141

ISSN: 1774-4296

\section{Electronic reference}

James N. Andrews, "Revisiting the upper floors of the Casa d'Argo at Herculaneum*", Anabases [Online]

26 | 2017, Online since 01 November 2020, connection on 20 January 2021. URL: http://

journals.openedition.org/anabases/6326 ; DOI: https://doi.org/10.4000/anabases.6326

(c) Anabases 


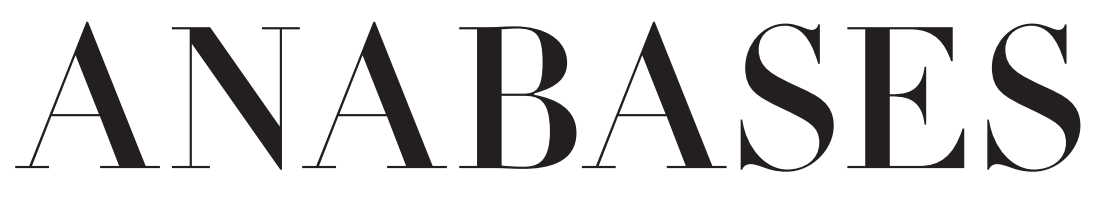

Traditions et Réceptions de l'Antiquité

$$
\begin{aligned}
& N \circ 26 \\
& 2017
\end{aligned}
$$

\section{E.R.A.S.M.E.}

Université Toulouse - Jean Jaurès 



\section{Sommaire}

$\mathrm{N}^{\circ} 26-2017$

\section{Historiographie et identités culturelles}

Jocelyne Peigney

La polysémie poétique d'anabase chez Saint-John Perse :

évocations, étymologie et botanique $\ldots \ldots \ldots \ldots \ldots \ldots \ldots \ldots \ldots \ldots$

Nicolas FAELLI

Les références antiques des fondateurs de l'Amérique française

au XVII siècle ................................. I9

Silvia Alaura

Setting the stage for Hittite studies in Victorian England:

practices and methods of the 1870 . . . . . . . . . . . . .

\section{Traditions du patrimoine antique}

“ Restituer Herculanum I. Des archives de fouilles aux restitutions 3D »

Alexandra Dardenay et Adeline Grand-Clément

Restituer Herculanum au XXI ${ }^{\mathrm{e}}$ siècle. L'apport des archives. . . . . . . . 55

Antonella Coralini

In situ e alibi, dallo scavo integrato alla cultura dell'abitare :

Vesuviana-DHER a Ercolano . . . . . . . . . . . . . . . . 67 67

Agnes Allroggen-Bedel

I documenti settecenteschi come strumenti per lo studio

degli scavi ercolanesi . . . . . . . . . . . . . . . Io3

James ANDREws

Revisiting the upper floors of the casa di Argo at Herculaneum . . . . . . II7 
Nicolas MonteIx

Les archives des fouilles d'Herculanum au XX $\mathrm{XX}^{\mathrm{e}}$ siècle :

analyse critique et pistes d'exploitation . . . . . . . . . . I43

\section{Archéologie des savoirs}

Yannick Le PAPE

L'inspiration et l'imprudence. Poésie de l'anticomanie

dans la critique d'art du second XIX ${ }^{\mathrm{e}}$ siècle . . . . . . . . . . . . . I57

\section{Actualités et débats}

Claude AzızA

Antiquités parallèles (7). La starlette des bandelettes . . . . . . . . . I77

Alexandra TrachseL

La réception d'Homère dans le domaine de la rhétorique $\ldots \ldots \ldots$. . . I83

Claude Aziza

Curiosa (2) In vino (vin/eau) veritas (very tasse) : drame de l'ivresse . . . . I89

\section{Lire, relire la bibliothèque des sciences de l'Antiquité}

Laurent OLIVIER

Pour en finir avec la race : Henri Hubert et l'anthroposociologie

À propos du commentaire de “L'Aryen, son rôle social », de Vacher de Lapouge $(\mathrm{r} 899) \ldots \ldots \ldots$

Henri Hubert

Compte rendu de Georges VACher de LAPouge, L'Aryen, son rôle social, L'Année sociologique, igoo, p. i45-146 . . . . . . . . . . . . . . . . . 203

\section{L'atelier de l'histoire : chantiers historiographiques}

L'Atelier des doctorants (coordonné par Adeline Grand-Clément) (14)

Francesco LoDÀ,

L'initiation des guerriers chez les peuples indo-européens.

Une enquête historiographique dans les pas de Georges Dumézil . . . 207

\section{Comptes rendus}

Benjamin Anderson et Robert G. Ousterhout

Palmyra I885. The Wolfe Expedition and the photographs

of John Henry Haynes (M. Sartre) . . . . . . . . . . . . . . . . . . . 2 215 
Mary R. BAchvarova

From Hittite to Homer. The Anatolian Background of Ancient Greek Epic (G. Hoffmann) . . . . . . . . . . . . . . . . .

Patrick Baker, Ronny Kaiser, Maike Priesterjahn, Johannes Helmrath (éd.) Portraying the Prince in the Renaissance. The Humanist Depiction of Rulers in Historiographical and Biographical Texts (G. Demelemestre). . 220

Brigitte BAKHоUсHE (éd.)

Science et exégèse. Les interprétations antiques et médiévales du récit biblique de la création des éléments (Genèse I, I-8) (F. P. BARONE) . . . . . . .

Laurence Baurain-Rebillard (éd.)

Héros grecs à travers le temps : autour de Persée, Thésée, Cadmos et Bellérophon (C. Giovénal) . . . . . . . . . . . . . . . .

Mark W. PAdiLla,

Classical myth in four films of Alfred Hitchcock . . . . . . . . . . . . . . .

Vivien Bessieres

Le Péplum et après? L’Antiquité gréco-romaine dans les récits contemporains (Cl. Aziza) . . . . . . . . . . . . . . . . . 225

Pierre Briant

Alexandre. Exégèse des lieux communs (É. Guillon) . . . . . . . . . . . . . 227

Paulo ButTi DE Lima

Il piacere delle Immagini. Un tema aristotelico nella riflessione moderna sull'arte (C. Noacco) . . . . . . . . . . . . . . . . . . .

Bénédicte Coudì̀re

La truelle et le phylactère. La proximité des images (M. Scapin) . . . . . . . 23I

Thorsten Fögen, Richard WARREN (éd.)

Graeco-Roman Antiquity and the Idea of Nationalism in the rgth Century, Case Studies (M. Champier) . . . . . . . . . . . . . . . ${ }_{232}$

Ronald H. Fritze

Egyptomania. A History of Fascination, Obsession and Fantasy

(Fabien Bièvre-Perrin) . . . . . . . . . . . . . . . . . . . . . 234

Joseph Geiger

Hellenism in the East. Studies on Greek Intellectuals in Palestine

(C. Bonnet). . . . . . . . . . . . . . . . . 236

Tiffany Jenkins

Keeping their marbles. How the treasures of the past ended up in museums... and why they should stay there (C. Valenti) . . . . . . . . . . 238 
Ayelet H. Lushkov

Magistracy and the Historiography of the Roman Republic.

Politics in Prose (C. Landrea) . . . . . . . . . . . . . . . . . . . . . . 240

Jean-Claude MüHLEthaler

Énée le mal-aimé. Du roman médiéval à la bande dessinée

(Fl. Bouchet) ........................ 24I

Laurent PERNoT

Epideictic Rhetoric, Questioning the Stakes of Ancient Praise

(C.Psilakis) ......................... 243

Priscian

Answers to King Khosroes of Persia (O. Gengler) . . . . . . . . . . . . . . 245

Paul Robertson

Paul's letters and contemporary Greco-Roman literature:

theorizing a new taxonomy (M. Cambron-Goulet) . . . . . . . . . . . . . . 247

Federico Santangelo (éd.)

Approaching the Roman Revolution. Sir Ronald Syme,

Papers on Republican History (C. Landrea) . . . . . . . . . . . . . . . . . . 249

Molly Swetnam-BurLand

Egypt in Italy. Visions of Egypt in Roman Imperial Culture

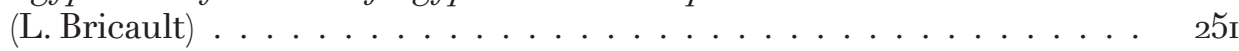

Helen VAN Noorden

Playing Hesiod. The 'Myth of the Races' in Classical Antiquity

(D. Bonanno)

Résumés . . . . . . . . . . . . . . . . . . . . . . . . . . . . . . . 257

Index .......................... . . 265 


\section{Traditions}

\section{du patrimoine antique}

Restituer Herculanum I.

Des archives de fouilles aux restitutions 3D 



\section{Revisiting the upper floors of the Casa d'Argo at Herculaneum*}

James N. ANDREws

The Casa d'Argo (II, 2) was the first house revealed by the open-air excavations at Herculaneum. Only the eastern half of the house was completely excavated, while the western half, which was extensively explored by tunnels in the Bourbon period, still remains buried beneath the modern town. The Casa d'Argo was one of a number of elite residences that commanded an impressive view of the shoreline in the southern zone of the town. Today the house appears in a rather ruinous condition (fig. 1) although at the time of its excavation (1828-1830) it featured the impressive remains of upper floors (cenacula) that also bore extensive food remains. By 1835 these had been dismantled due to their fragile state, allegedly exacerbated by the dumping of rubbish from above by the local population, to the later vehement criticism of Amedeo Maiuri '. Fortunately, the historic records of the excavation are such that we are able to understand much of the upper floors' original character and contents. Yet to date there has been no attempt to reconcile any of these records

* I would like to thank Dott.ssa Maria Paola Guidobaldi of the Ufficio Scavi di Ercolano (now Parco Archeologico di Ercolano) for allowing generous access to many of the closed buildings at Herculaneum and the Parco Archeologico di Pompei for similarly granting me permission to carry out the required fieldwork at Pompeii. I would also like to extend thanks to Dott. Francesco Sirano of the Parco Archeologico di Ercolano and The British Library for kindly giving permission to reproduce archive images and photographs of the sites.

1 C. Bonucci, Le due Sicilie. Ercolano, Napoli, 1835, p. 42 : 'Il cattivo stato delle fabbriche superiori, le scosse che avevano ricevuto dai terromoti, e dalla eruzione, e la mancanza degli architravi e di tutti legnami divenuti carboni... mi obbligarono mio malgrado a demolirle.' (A. MaIuri, Ercolano. I nuovi scavi (1927-1958), Roma, 1958, p. 6, ft. 7). 


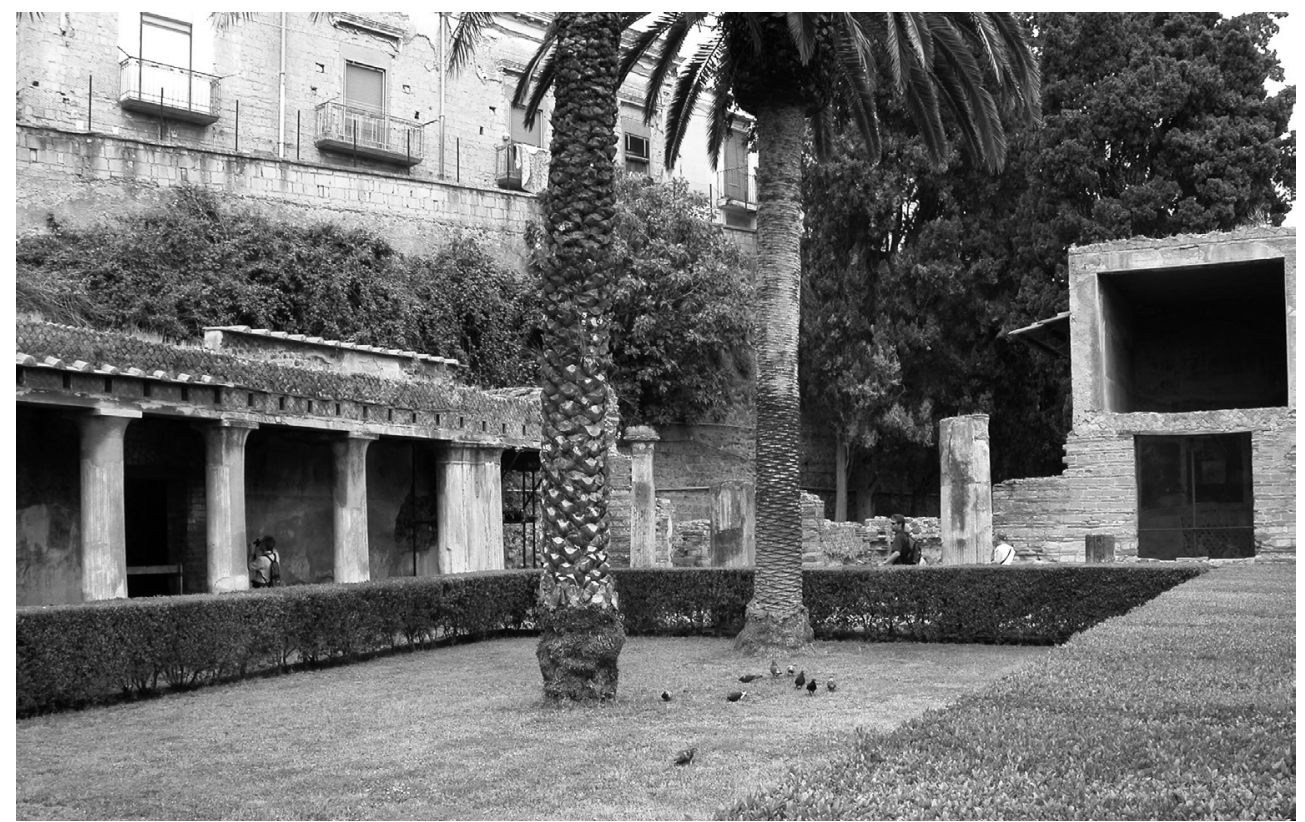

Fig. 1. View of the large peristyle of the Casa d'Argo towards the northwest. Photograph by the author and published with the permission of the Parco Archeologico di Ercolano.

with the surviving remains beyond the initial report and description of the upper floors by its excavator, Carlo Bonucci, and later overview of the principal findings by Maiuri ${ }^{2}$. The aim here is to redress this situation by reconstructing these records and also to reassess their significance in the wider context of spatial use in the upper floors of the Roman house.

The Casa d'Argo was rapidly excavated between 1828 and the late summer of 1830 under the auspices of Carlo Bonucci with progress recorded in a daily diary, the Giornale degli Scavi, now conserved in the Archivio Storico in Naples ${ }^{3}$. This was supplemented by monthly summaries, drawings, plans and letters written by Bonucci. These important documents were collated and largely published several decades later by the then director of the excavations at Pompeii, Michele

2 A. Maiuri, Ercolano, p.369-372. Maiuri's contribution to the study of the house consists mainly of this account of the principal findings. See also C. Montella, La Casa d'Argo ad Ercolano, Tesi di specializzazione in archeologia e storia dell'arte romana, University of Bari, 2008, p. 31-34.

3 C. Bonucci, Le due Sicilie, p. 40-42. 
Ruggiero, following the initiative of his predecessor, Giuseppe Fiorelli, to publish the records from the earliest excavations ${ }^{4}$. Ruggiero's volume also included many of the records from the earliest explorations of the Bourbon period as well as the successive excavations of the $19^{\text {th }}$ century. One of these plans made during the excavation of the upper floor above the west side of the peristyle and now in the Archivio Fotografico of the Parco Archeologico di Pompei, bears a series of room numbers which can be related to numbers for rooms in an entry in the original Giornale degli Scavi as published by Stefan Mols, but missing in the version as published by Michele Ruggiero, thus aiding our ability to elucidate some of the locations referred to ${ }^{5}$. The records of Bonucci are admirable for the time, especially when compared to the paucity of documentation afforded to upper floors at the same time at Pompeii, where their remains were typically discarded ${ }^{6}$. Indeed, Bonucci was able to produce a number of plans, sections and elevations of the house, including the upper floors, which were presented in his 1835 volume on the excavations ${ }^{7}$. Bonucci's thoroughness is best illustrated by his fascinating account of having to crawl on his hands and knees through the earlier Bourbon cunicoli in order to reconstruct a ground plan of the house (fig. 2), limited as he was in excavating the whole house by the presence of a road and housing above ${ }^{8}$. The plans made from this exercise reveal a number of important details; in particular, the ground plan of the house appears to show that the atrium of the house, only partially cleared, was aligned from south-north, the smaller peristyle to the west included a number of possible reception rooms on its north side and there was a long range of rooms along the house's west façade, bordering Cardo II, which

4 M. Ruggiero, Storia degliscavi di Ercolano ricomposta su'documentisuperstiti, Napoli, 1885, p. 538-565.

5 Pompei, Archivio Fotografico P639; S. Mols, Wooden furniture in Herculaneum: form, technique and function, Amsterdam, 1999, p. 229 ('Archivio Storico VII, C. 9, Fascicolo 2 Giornale de' R. Scavi d'Ercolano No 3, marzo 1828’).

6 That this was the case is made clear by Englishman Edward Falkener, an architect and antiquarian who witnessed and documented the excavation of the Casa di M. Lucretius (IX 3, 5.24) at Pompeii in 1847. Falkener observed that numerous finds were made at the level of the upper floor, as well as fragments of upper floor mosaic pavement, upper floor ceiling decorations and fittings. Sadly, these went entirely undocumented by the excavators and were subsequently discarded. See E. Falkener, "Report on a House at Pompeii, excavated under personal superintendence in 1847 », The museum of classical Antiquities. Being a series of essays on Ancient art, vol. 2, London, 1860, p. 69.

7 C. Bonucci, Le due Sicilie, figs. 11 (ground plan), 12 (upper floor), 13 (un-numbered but a detail plan of the upper floors above the eastern wing of the house), 14 (reconstructive elevation of the East façade), 15 (reconstructive section).

8 M. Ruggiero, Storia degli scavi di Ercolano, p. 564. 


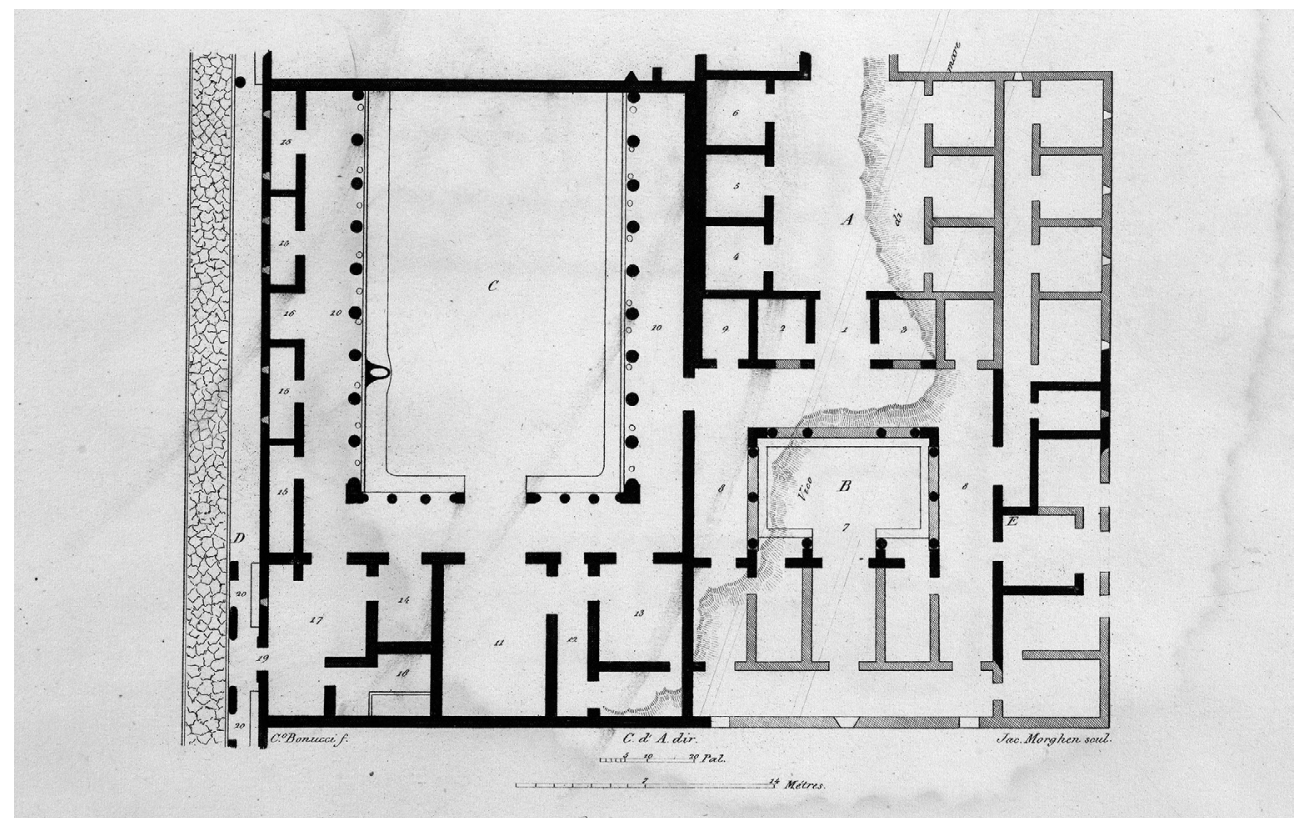

Fig. 2. Plan of the ground floor of the Casa d'Argo by Bonucci (Bonucci 1835, fig. 11: 'Casa d'Argo - Pian terreno', (c) British Library Board 7708.ee.36). Plan orientated with south at top and north at bottom.

included yet another street entrance ${ }^{9}$. Concurrent surveys were made by others alongside those of Bonucci, which he appears to have encouraged ${ }^{10}$. A very similar ground plan and section of the house was published in the Real Museo Borbonico by the archaeologist, architect and later superintendent of the excavations at Pompeii Gugliemo Bechi. These were produced by the architect Fausto Niccolini, although are identical to Bonucci's drawings besides a few points of detail "'. Another important source for the upper floors of the Casa d'Argo are the architectural watercolours and drawings published by Wilhelm Zahn (18001871), a German architect, artist and art critic who also produced many works of wall paintings and decorations from Pompeii in the same period. Zahn's works of

9 C. Bonucci, Le due Sicilie, fig. 11.

10 Ibid., p. 42 : 'Credo però di far cosa grata agli Artisti, e agli Eruditi di pubblicarle nella loro integrità , avuto riguardo alla circostanza, ch' esse formano un monument il più prezioso , offrendoci l'esempio unico d' un secondo piano, che niun altro scavamento ci ha somministrato fin' oggi?

1 G. BEchi, «Iconografia e Ortografia dei nuovi Scavi di Ercolano », Real museo Borbonico 7 (1831), tav. LIX. 
the Casa d'Argo included a section across the northern part of the house with its upper floors and mostly-buried western peristyle, an elevation of the east façade, another detailing the stuccoed decoration on the columns in both peristyles as well as copies of the wall paintings in a few of the rooms ${ }^{12}$. The sections are highly detailed and appear to be consistent with the accounts and corresponding records of Bonucci with which they can be compared. Evidently, as Zahn was also reproduce such details suggests he was similarly able to view their remains, via the network of cunicoli, as had Bonucci.

\section{The upper floors}

On the evidence provided by these sources we can broadly understand the arrangement of the upper floors across the whole house and some parts in considerable detail. The upper floors of the Casa d'Argo were divided into at least two separate units (fig. 3). The first of these extended above the rooms on the west side of the large peristyle as well as much of the still-buried western part of the house including around the atrium, around the small peristyle and probably above the rooms along the house's western flank, while the second smaller upper floor stretched above the east side of the large peristyle. Maiuri indicates the upper floors were accessed by two separate staircases, one located in a room to the northwest of the small peristyle and another in room 1 (fig. 4) ${ }^{13}$. Regarding the latter, it is unclear on what this assertion was based particularly as no stairs were mentioned in the records of Bonucci as published by Ruggiero ${ }^{14}$. However, Wilhelm Zahn's 1842 plan of the house, which wasn't referenced by Maiuri, confirms the presence of both staircases; the first located in the southeast corner of the entrance vestibule (1), shown rising in a southerly direction above room 8 , and the second of two flights in a room to the northwest of the still-buried small peristyle presumably revealed through exploration of the cunicoli $^{15}$. The staircase

12 W. ZaHn, Die schönsten Ornamente und merkwürdigsten Gemälde aus Pompeji, Herculanum und Stabiae nebst einigen Grundrissen und Ansichten nach den an Ort und Stelle gemachten Originalzeichnungen. Band 2, Berlin, 1842, taf. 39, 63-66, 69.

13 A. Maiuri, Ercolano, p. 371.

14 Ibid., p. 477, ft. 179.

15 W. ZAHN, Die schönsten Ornamente und merkwürdigsten Gemälde, taf. 63. The first flight of the staircase to the northwest of the small peristyle is depicted by Zahn rising in a westerly direction to what appears to be a landing, then the second flight continued in an easterly direction to the level of the upper floor. A small splayed window in the west wall, which appears to have taken light from Cardo II, provided the stair with light. Zahn's plan was later replicated by Barker (E.R. BARker, Buried Herculaneum, London, 1908, plan 8). 


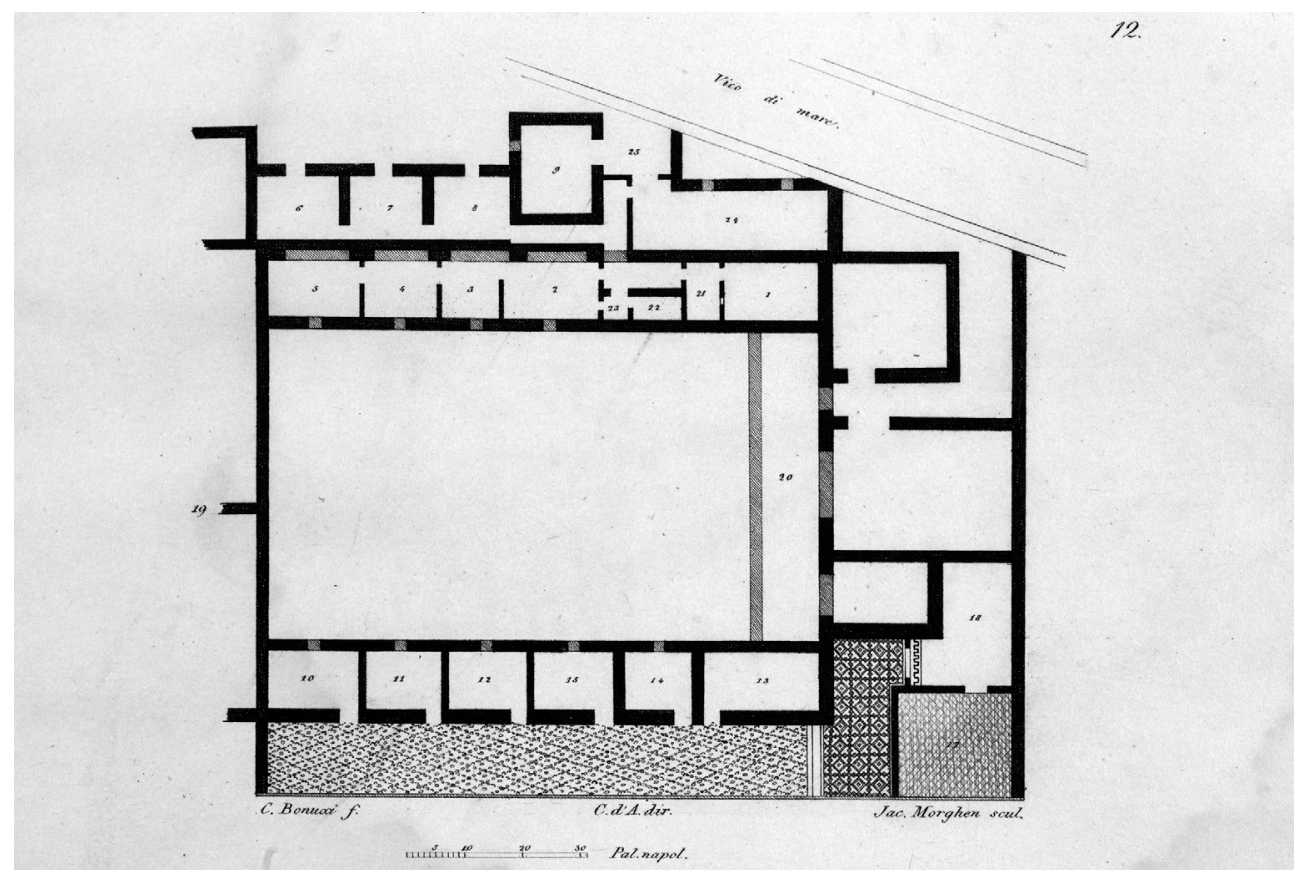

Fig. 3. Plan of the upper floors of the Casa d'Argo by Bonucci (Bonucci 1835, fig. 12 : 'Secondo piano della casa d' Argo. PIANTA', (c) British Library Board 7708.ee.36). Plan orientated with north on right and south on left.

in room 1 is also shown on Zahn's section of the house (fig. 5) which shows the staircase rising to a doorway in the south wall of a room on the upper floor ${ }^{16}$.

The double-flight staircase evidently provided access to an upper floor gallery that extended above the west, south and east sides of the small peristyle and very likely also the range of rooms that extended along the entire west side of the Casa d'Argo, flanking Cardo II. It is uncertain whether there was an upper floor above the three large rooms and access passage behind to the north of the small peristyle, although their size is suggestive of reception rooms which in turn typically implies higher ceilings. In the Casa dei Cervi (IV, 21) the upper floor above the northern part of the house extended around the south-facing black triclinium by means of a corridor above the service corridor below. A similar upper corridor may then have existed above the access passage. However, if it did then it was unconnected to the gallery above the east side of the small peristyle and so is probably unlikely. With respect to the form of the upper storey above the small peristyle, the sections left by Bonucci, Bechi and Zahn all indicate that this had a closed parapet 


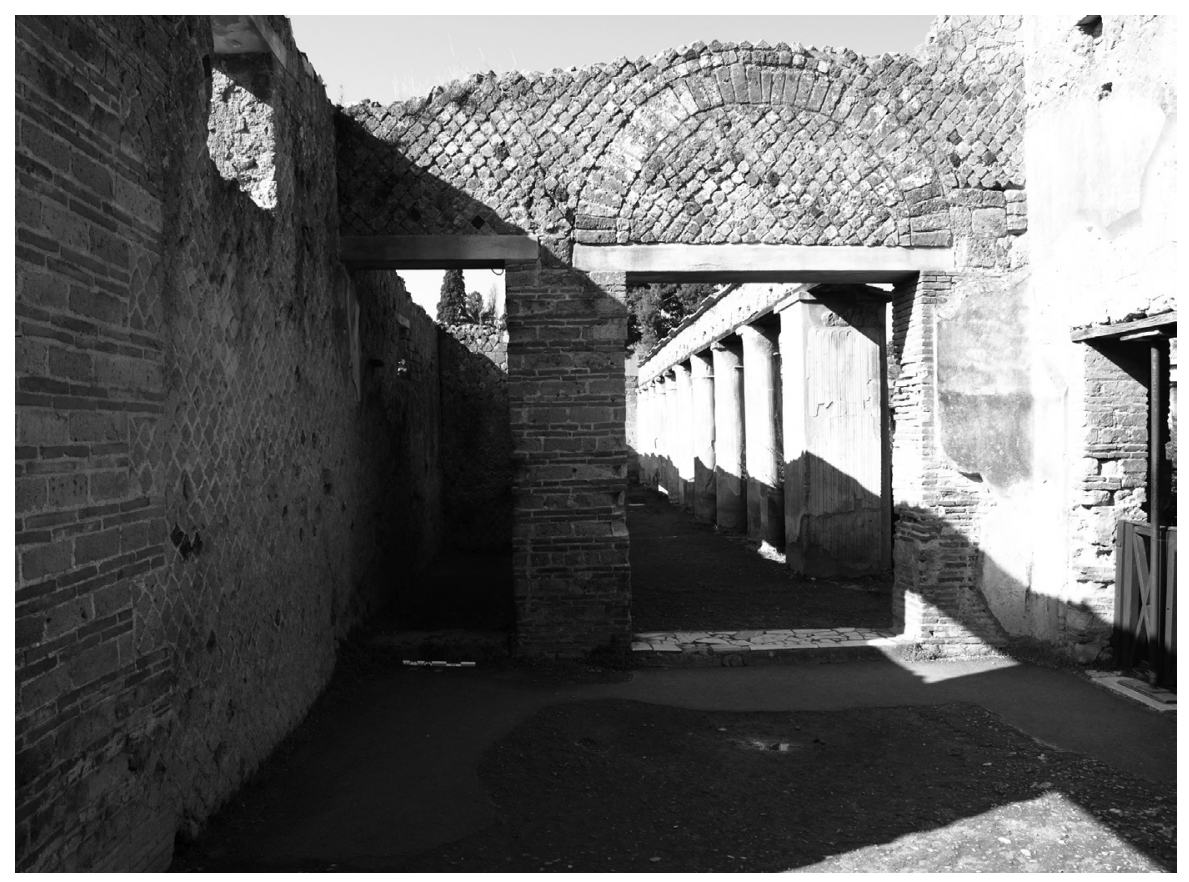

Fig. 4. Entrance to staircase to upper floor above east side of the large peristyle.

South wall room 2. Photograph by the author and published with the permission of the Parco Archeologico di Ercolano.

wall in which were a series of small square windows providing the gallery, and any rooms opening off it, with light (figs. 5-6) ${ }^{17}$. Three windows are indicated in the southern gallery while further windows are shown in section in the east and west gallery parapet walls. The windows in the southern gallery are not, however, shown on any of the plans of the upper floor although two are indicated in the east gallery wall on Bonucci's plan, so we must assume that these last two provided the evidence for the reconstructive sections. Bonucci provides no information as to the existence or character of any wall decorations in the gallery and none are shown on his section. In contrast, Zahn's section of the house (fig. 5) depicts two slightly different field schemes both on a white ground on the south walls of the east and west wings. However, that on the south wall of the east wing should show part of a small partition relating to a narrow corridor, described below, with a doorway at its west end. Yet Zahn's section suggests a flat wall extending for

17 G. BechI, « Iconografia e Ortografia dei nuovi Scavi di Ercolano », Real museo Borbonico 7 (1831), tav. LIX; Bonucci, Le due Sicilie, fig. 15; ZaHN, Die schönsten Ornamente und merkwürdigsten Gemälde, taf. 65. 


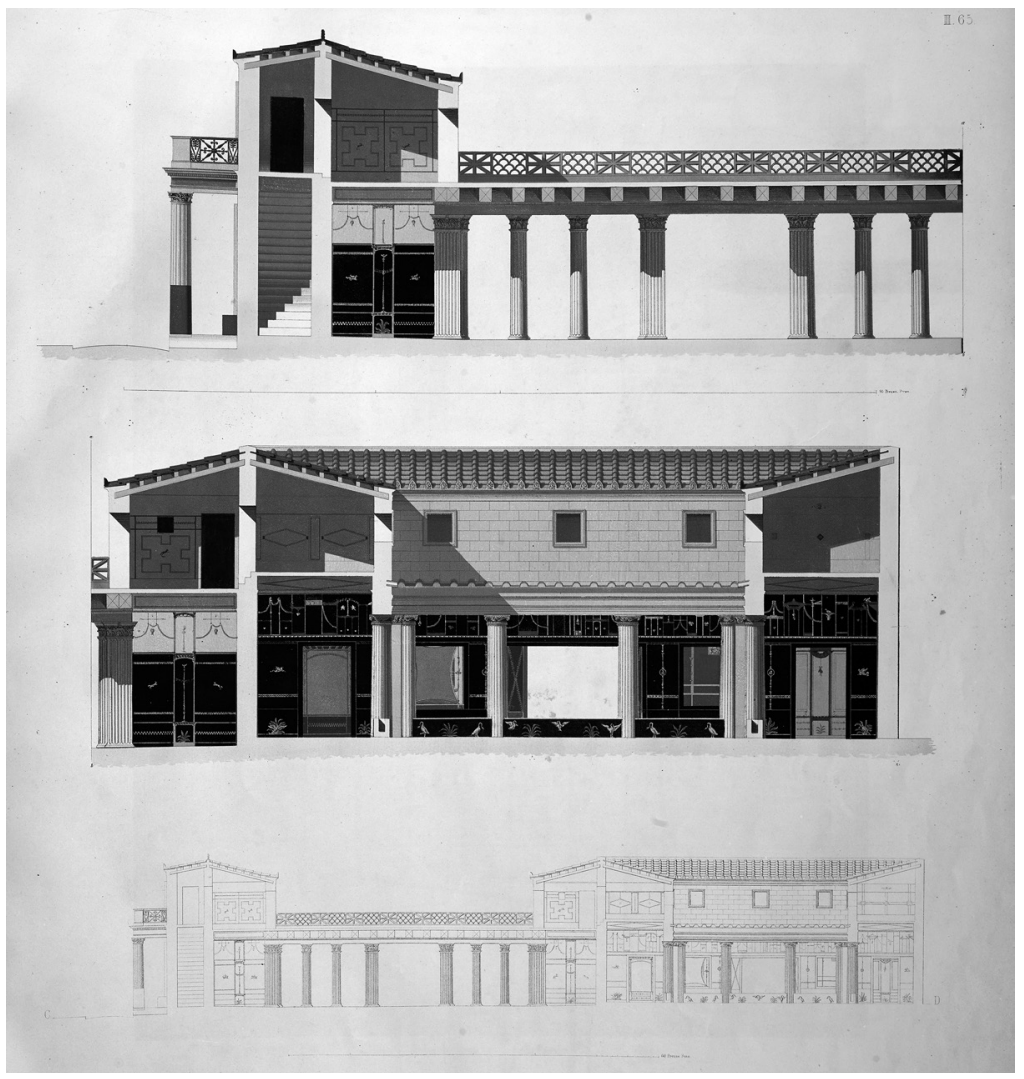

Fig. 5. Section of the Casa d'Argo by Zahn (Zahn 1842, vol. 2, taf. 65:

'Durchschnitt der Casa d'Argo e d'Io in Herculanum, ausgegraben 1828 - 1838', (C) British Library Board 1899.h.3).

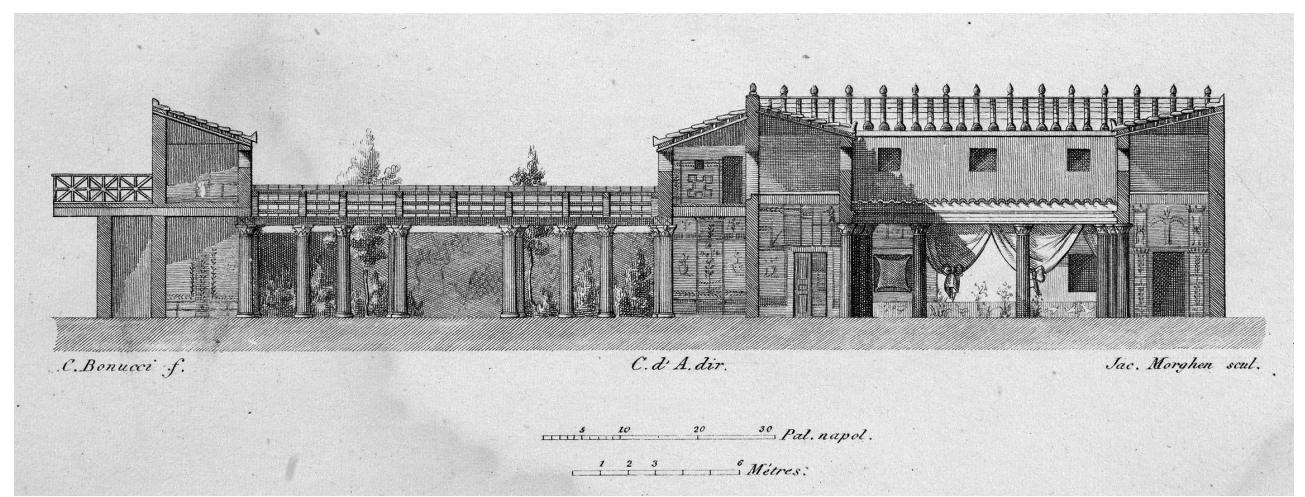

Fig. 6. Section of the Casa d'Argo by Bonucci (Bonucci 1835, fig. 15: 'Casa d'Argo. SEZIONE., (C) British Library Board 7708.ee.36). 
the full width of the gallery. Consequently, the decorations should most likely be viewed as the result of artistic licence.

At least one and probably further rooms opened off the southern wing of the upper floor gallery above the small peristyle corresponding with the tablinum and other rooms below that were between the atrium and the small peristyle (fig. 3). This rectangular room, indicated as room ' 9 ' on Bonucci's plan of the upper floor, was situated above rooms 16 and 17 and had a window in the south wall that we must assume took light from the atrium. Some bronze window fittings, noted by Bonucci in the Giornale, probably belonged to the same window whilst several pieces of polychrome marble flooring were also found in this room, although it is unclear whether these were loose pieces in storage or comprised part of the room's floor surface. Bonucci also notes the finding of a small wooden chest containing bronze and silver coins as well as a number of other items and food remains, including wheat and spelt ${ }^{18}$. Returning to the upper floor gallery above the small peristyle, in its southeast corner was added a narrow corridor that gave access to three rooms above the eastern side of the atrium and also the upper floor above the west side of the large peristyle ${ }^{19}$. Close to this corridor at the east end of the north side of the southern gallery was a further, short north-south aligned projecting wall. This appears to have been the findspot of a well-preserved wooden cabinet, fitted with locks, on top of which were found several vessels and with further vessels inside; one of these contained figs that had been split in half and wrapped in laurel leaves and another contained wheat ${ }^{20}$. Of the eastern wing of

18 M. Ruggiero, Storia degli scavi di Ercolano, p. 549-550 (5, 17 May 1828), p. 551 ('Giornale de' R. scavi d' Ercolano - N.' 5 - Maggio 1828'), p. 553 (13 Jun. 1828). That this was indeed the findspot is confirmed by the second and third of the above entries which describe the large room and adjacent corridor, whilst the final entry cited (13 Jul. 1828) follows a description of room 17 (Ruggiero room 9) and describes the upper floor room as 'stanza superiore', thus implying the room above. Of the window fittings, Bonucci only notes these included a handle and 'altri finimenti'. Their present location is unknown.

19 The archive plan of the upper floor at Pompeii (Pompei, Archivio Fotografico P639) simply shows a single partition wall projecting from the east wall of the gallery, thus opening towards the east, whilst Bechi's plan shows a second wall projecting from the south wall of the gallery, with a short easterly return then facing the first wall and the gap between the two forming a doorway, in the east end of the north wall of the corridor. M. Ruggiero, Storia degli scavi di Ercolano, p. 546 (10, 17 Mar. 1828), 547 ('Giornale de' R. scavi d' Ercolano - N. 3 - Marzo 1828'), 550 (11 May 1828). The descriptions of the cabinet vary in their detail particularly in relation to the finds made. It is therefore difficult to determine whether initial descriptions of the finds were incorrectly described or whether the subsequent discrepancies reflect different objects that had previously been neglected. On top of the cabinet were found a glass cup or small carafe 
the upper floor gallery (room '24' on Bonucci's plan of the upper floor), no details are provided by Bonucci other than descriptions of the finds which included a bronze basin, a glass plate and a small wooden chest with iron and bronze fittings and lock. According to Bonucci the chest was full of dough that had mixed by the 'eruptive water' and which had been cooked by the heat of the eruption ${ }^{21}$. The corridor in the southeast corner of the upper floor gallery gave access to another

and a terracotta jug. The glass vessel is mentioned twice by Bonucci; first on the $10^{\text {th }}$ of March 1828 when it is referred to as a 'caraffine' and then apparently again during a summary of the month's findings it is seemingly described as a 'tazzette', with the jug. The contents of the cabinet were as follows: a bronze bracelet with serpent heads, some shells, two terracotta lamps, one of which bore the relief of a cock and a number of terracotta vessels, which are described as being stacked, one on top of another. The terracotta vessels included two conical vessels one of which contained 20 dried figs split in half, in the manner advocated by Horace (Sat. 2.2.122) and Columella (Rust. 12.15.5), and wrapped in laurel leaves while the other contained wheat grains. Other vessels, in glass and terracotta, are described as containing the desiccated remains of an unidentified liquid in the bottom. An unspecified number of the figs, the terracotta lamp with the relief of the cock, a nut, possibly a walnut from the eastern gallery and some honey and lentils, probably those found in the small storeroom (see below), were subsequently given as a gift to Prince Frederick Augustus of Saxony (later King Federick II of Saxony, 1836-1854) on the 11 $1^{\text {th }}$ of May 1828 (M. Ruggiero, Storia degli scavi di Ercolano, p. 550). The donation of figs is also noted by Borgongino (M. Bongongino, Archeobotanica. Repertivegetali da Pompei e dal territorio vesuviano, Roma, 2006, p. 154) but does not then connect these with those in the Museo Archeologico Nazionale in Naples (see 2006, 88-89, no. 172).

21 M. Ruggiero, Storia degli scavi di Ercolano, p. 538 (21 Jan. 1828), 540 ('Giornale de’ R. scavi di Ercolano - No 1 - Gennaio 1828'), 541 (7 Feb. 1828), 548 ('Giornale de' R. scavi d' Ercolano - N 3 - Marzo 1828').' Bonucci also indicates that the chest and plate were found at some height above the room's floor, having 'floated' due to the 'aqua' that had entered the room and which had then remained in situ as the deposit solidified. The dough was covered by the carbonized remains of a cloth and a walnut was also found. Also in this spot were an amphora with olives and a vessel for olive oil. The chest with cooked dough is noted on four occasions in Ruggiero's publication of Bonucci's Giornale entries and letters to Michele Arditi, the superintendent at Pompeii at this time, although there are numerous differences in the details given between them. Initially, for example, the chest is referred to as a 'casettino' yet in the subsequent summary it has become a 'cassa' while in the final reference to it, in March 1828, it is described as an 'ampia cassa'. In his last report in March of 1828, Bonucci also goes further in his description, informing us that the flour seemed to have been mixed with honey, milk and oil although there is no way of knowing on what evidence this unusual assertion was based. Such differences in the varying accounts highlight their unreliability. 
to the south and then to three rooms (rooms ' $6-8$ ' on Bonucci's plan of the upper floor) situated above the rooms (18-20) on the east side of the atrium. The rooms were interconnected by doorways at the east end of the respective dividing walls and each with a window in its west wall, evidently overlooking the atrium. We can assume that there was a corresponding series of rooms above the atrium's western rooms, perhaps accessed in a similar way. One of the three rooms on the east side can probably be identified as the well-decorated room mentioned several times during the excavations in the Giornale degli Scavi. Indeed, this room, which is described as being located 'behind' the rooms with the niches, was marked out specifically by Bonucci as being the only well-decorated room on this part of the upper floor, decorated with a mosaic floor and fine wall paintings in a red scheme. The room's door was apparently equipped with a large circular lock which was found along with several other items ${ }^{22}$. Perhaps also in this area was found a large quantity of grain with a wooden scoop resting on top, although no precise details are given of the findspot ${ }^{23}$.

The upper floor above the western wing of the large peristyle was divided into a series of utilitarian rooms of varying size, shape and alignment (fig. 3). A modern floor has been restored for its entire length although all of the dividing walls that survived at the time of its excavation were lost during the demolition of the upper floor. Originally at its northern end was a large rectangular room, to the south of which was a narrow storeroom shown on Bonucci's plan of the upper floor as rooms ' 1 ' and '21' respectively. Bonucci's account of these two rooms can be reconciled with the published and archival plans and allows us to define their character in some detail ${ }^{24}$. The larger room was separated from its neighbour by a narrow partition wall carried out in opus craticium; a doorway at the west end of this wall provided access between the two. Bonucci informs us that the larger room was decorated in simple field paintings on a white ground with figures of lions, goats and eagles, with spread wings, in red while the floor was opus signinum and supported by large wooden beams that were well-preserved at the time of excavation. Some of the plaster that bore these paintings still survives although the details of the scheme are now almost entirely lost. ${ }^{25}$ However, a

22 M. Ruggiero, Storia degli scavi di Ercolano, p. 555 (25 Jul. 1828), p. 556 ('Giornale de' R. scavi d'Ercolano - No 7 - Luglio 1828'), p. 557 (29 Sep. 1828).

23 Ibid., p. 556 ('Giornale de' R. scavi d'Ercolano - No 7 - Lugio 1828').

24 M. Ruggiero, Storia degli scavi di Ercolano, p. 538 (13 Jan. 1828), p. 539 (21 Jan. 1828), p. 540 ('Giornale de' R. scavi di Ercolano - No 1 - Gennaio 1828'), p. 542 (14 Feb. 1828).

25 The details of the scheme were evidently still visible in the 1920s as is clear from an archive photograph taken prior to the recommencement of excavations in the same decade by Amedeo Maiuri (Pompei, Archivio Fotografico: C2703 (previously E C368). 
colour drawing was made of the wall paintings in the Giornale degli Scavi and another by Zahn (fig. 7) provide an invaluable record for the precise nature of the scheme ${ }^{26}$. Particularly unusual are the geometric frames of the two central fields, seemingly without parallel at Herculaneum, whilst the two flanking fields with square frames are similar to those found in a number of other houses at the site. The same decorative scheme appears in both Bonucci's and Zahn's reconstructive sections of the house ${ }^{27}$. More unusual is that Bonucci indicates that the room was covered by a roof for part of its length while part was unroofed in order to provide light to the adjacent storeroom, through a window. Also at this end of the room appears to have been an opening for a chimney flue that was blackened through use. Bonucci notes his intention to determine the function of the flue through further excavation although, sadly, no mention of any such feature is consequently described, even in his subsequent summary of the month's finds, nor is the flue shown on the plans of the upper floor. The role of the chimney flue must therefore be assumed; perhaps this was connected to a portable hearth that could have been easily dislocated during the eruption or by later tunneling, or was simply located in another part of the house at the time of the eruption. A second window in the east wall drew light from the garden ${ }^{28}$. The storeroom to the south was disposed perpendicularly to that just described. Bonucci provides few details of this besides the impressive remains of two tiers of wooden shelving on metal supports on either side of the room on which were several objects ${ }^{29}$. The storeroom was accessed via

At that time, the modern surface of the upper floor above the west side of the large peristyle had yet to be installed and so the upper floor paintings were visible from the floor below.

26 A. Dardenay et alii, "Herculanum. Des archives aux restitutions architecturales et décoratives ", Chronique des activités archéologiques de l'École française de Rome (2016) (consulté le 9 novembre 2016, uRL = http://cefr.revues.org/1588), fig. 7; ZAHN, Die schönsten Ornamente und merkwürdigsten Gemälde, taf. 66.

27 G. BECHI, “ Iconografia e Ortografia dei nuovi Scavi di Ercolano », Real museo Borbonico 7 (1831), tav. LIX; ZAHN, Die schönsten Ornamente und merkwürdigsten Gemälde, taf. 65.

28 This may be the window mentioned twice by Bonucci (Ruggiero, Storia degli scavi di Ercolano, p. 538 (13 Jan. 1828), p. 540 ('Giornale de' R. scavi di Ercolano - No 1 Gennaio $\left.1828^{\prime}\right)$ ) although his description of it does not clearly specify its location.

29 Ruggiero, Storia degli scavi di Ercolano, p. 539 (21 Jan. 1828), 540, 542 (14 Feb. 1828). Bonucci's initial description of the shelving (21 Jan. 1828) includes the description of the storeroom in the general discussion of the large rectangular room, thereby not drawing a distinction between the two spaces. However, his subsequent account (14 Feb. 1828) indicates that the storeroom was at the end of the large room. Moreover, the plan provided on the same page is labelled as 'pianta della stanza e del ripostiglio descritti? 


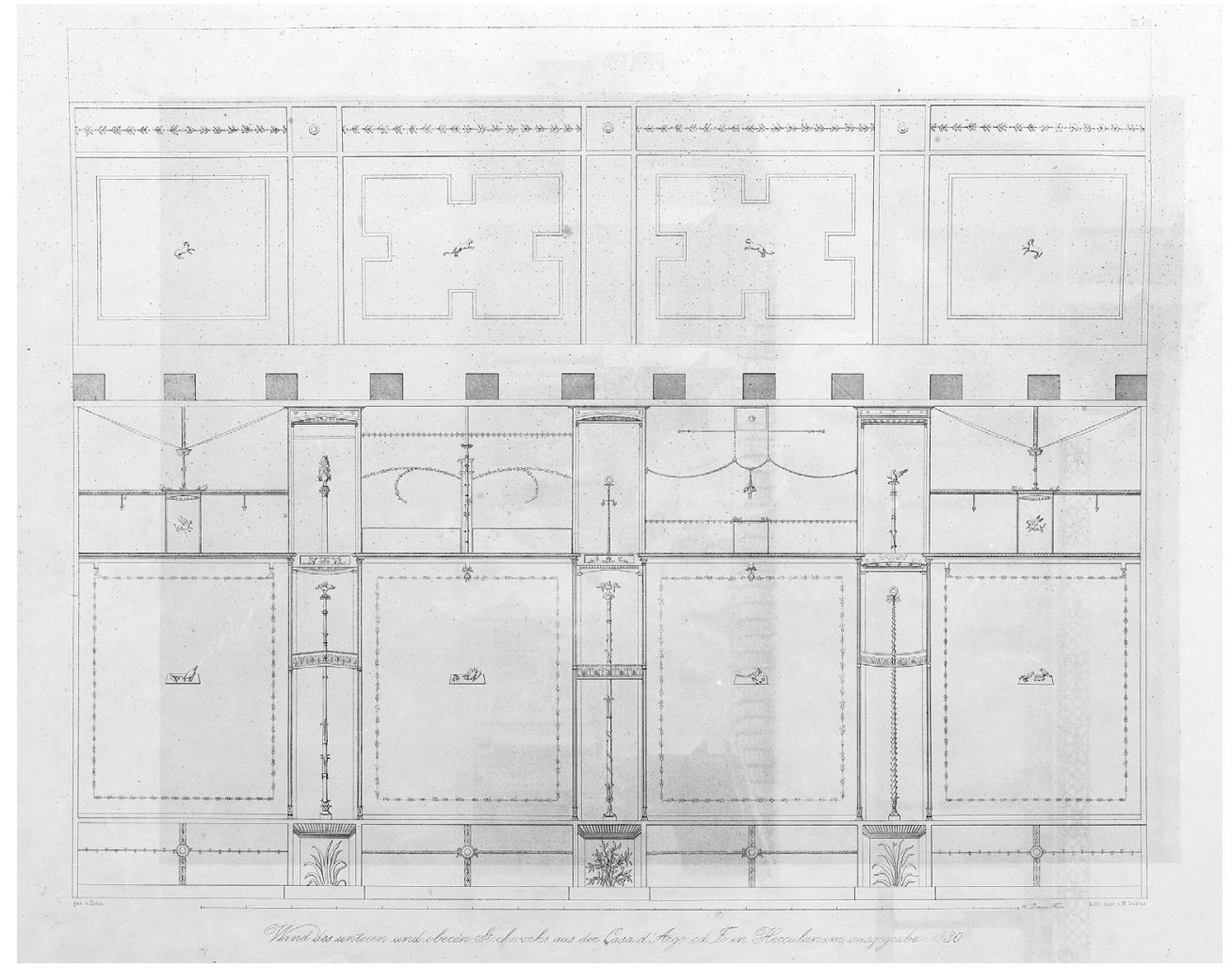

Fig. 7. Drawing of the wall paintings in the large room above the north end of the west wing of the large peristyle by Zahn (Zahn 1842, vol. 2, taf. 66: 'Wand des unteren und oberen Stockwerks aus der Casa d'Argo e d'Io in Herculanum, ausgegraben 1830, C British Library Board 1899.h.3).

a bifold door equipped with a large iron lock and appears to have been decorated in a similar fashion to the adjoining room; Bonucci notes figures of goats and tiny eagles.

Adjacent to the storeroom just described was a doorway in the south wall that gave access to a narrow corridor and further rooms to the south (fig. 3). The carbonized remains of the door, which appears to have been left ajar at the time of the eruption, were found during the excavation ${ }^{30}$. At the south end of the corridor were a number of doorways; one, in the west wall, in which Bonucci indicates

30 M. Ruggiero, Storia degli scavi di Ercolano, p. 541 (7 Feb. 1828), p. 543 ('Giornale de’ R. scavi d'Ercolano - No 2 - Febbraio 1828'). 
were wooden steps, gave access to the small corridor in the southeast corner of the upper floor gallery, already described ${ }^{31}$. Opposite this doorway was another storeroom, identified on Bonucci's upper floor plan as room '23', which was closed by two doors although few further details are given ${ }^{32}$. Partly as a result, but also given subtle differences that appear in the different plans of the room, it is difficult to determine with confidence exactly where these doors were situated ${ }^{33}$. However, next to this room was a further storeroom of which Bonucci provides a detailed account. This small room, marked on Bonucci's upper floor plan as room '22', contained the remains of wooden shelving on which were the remains of terracotta vessels filled with wheat and lentils, a jug with a cork stopper in the bottom of which was solidified olive oil and a glass jar with dried up liquor, two vessels for olive oil, some pig bones with, allegedly, the remains of salted meat and another vessel which was full of honey ${ }^{34}$. On the room's opus signinum floor were seven terracotta vessels. A narrow splayed window in the east wall provided limited light and ventilation ${ }^{35}$. The room's well-preserved wooden door was closed at the time of its discovery and is described as being like a portcullis. Bonucci notes that he had made a drawing of this although no such drawing appears in Ruggiero's publication of the excavations so we must assume that it was later lost. Finally, Bonucci describes the remains of this room's ceiling; this was formed by planks

31 Ibid., p. 547 ('Giornale de’ R. scavi d' Ercolano - No 3 - Marzo 1828’). Bonucci’s section of the house indicates two steps in the doorway, as does the archive plan of the upper floor, whilst Zahn's section indicates three steps.

32 Ibid., p. 547 ('Giornale de' R. scavi d' Ercolano - No 3 - Marzo 1828).

33 The plans of Bonucci and Bechi represent this storeroom as an enclosed space opening off the east side of the afore-mentioned corridor and almost forming an ante-room to yet another storeroom to the north to which a doorway provided access. Another doorway in the south wall provided access to a range of four large rooms located above the southern end of the western portico while a further doorway on the south side of the corridor also is shown as giving access to the same niched rooms. In contrast, the archive plan of the upper floor, in which it is labelled '2' shows no such separation of space from the corridor; presenting the two as contiguous with one another. In the south wall of this version were then the two doorways leading to the brick-niched rooms beyond.

34 Ibid., p. 541 (7 Feb. 1828), p. 541-542 (14 Feb. 1828), p. 542 (25 Feb. 1828), p. 543 ('Giornale de' R. scavi d' Ercolano - No 2 - Febbraio 1828'). It is unclear how Bonucci was able to determine that the meat remains were salted, although on the salting of meat see Cato, Agr. 162; Strab. 4.3.2-3. I am grateful to Janice Kinory (Institute of Archaeology, University of Oxford) for these references.

35 G. Rickman (Roman Granaries and Store Buildings, Cambridge, 1971, p. 20, 27, 39, 81, pl. 18.) indicates that at Ostia splayed slit-windows in the outer walls of horrea allowed a controlled level of light and ventilation. 
beneath which was a flat ceiling of plastered reeds and to which a whitewash had been applied ${ }^{36}$.

To the south of the rooms just described were a series of four rectangular rooms of varying size, indicated as rooms ' $2-5$ ' on Bonucci's plan of the upper floor, each with a low inset niche in the west wall and then a narrow window in the east wall opposite (fig. 3). Each of the rooms was separated from its neighbour by a narrow partition wall with a doorway at the west end of each providing access between them ${ }^{37}$. Bonucci suggests that the niches probably served as sleeping quarters for the slaves of the house. This assertion was not supported by any evidence. Slaves are notoriously difficult to identify in the archaeological record and it should be noted that no finds can be definitively assigned to these rooms with which to form any idea as to their use ${ }^{38}$. Moreover, they also appear too narrow to have accommodated sleeping. Finally, whilst the niches are without any direct parallel known to the author, they are reminiscent of the built-in cupboards found in some Pompeian alae whose significance has recently been highlighted by Elizabetta Cova $^{39}$. Perhaps the niches in Casa d'Argo simply served as inset storage spaces too, for whatever use.

There remain few signs of the upper floor that once extended above the rooms to the east of the large peristyle although the excavation records provide considerable information as to its character and arrangement. This was formed by a series of rooms above the eastern wing of the large peristyle that were accessed by means of a long balcony that extended above the rooms below and out above the street pavement (figs. 3, 8). Besides the balcony, Bonucci's plan of the upper floor indicates six rooms above the eastern wing of the peristyle and then a further three above rooms 1 and 2 at the northern end. The six rooms were entirely situated above the east wing of the peristyle while the balcony was cantilevered over the façade wall, partly extending above rooms 8-12 below and partly above the

36 M. Ruggiero, Storia degli scavi di Ercolano, p. 541 (7 Feb. 1828), p. $541-542$ (14 Feb. 1828), p. 542 (25 Feb. 1828), p. 543 ('Giornale de' R. scavi d' Ercolano - No 2 - Febbraio 1828').

37 Ibid., p. 547 (31 Mar. 1828, 'Giornale de' R. scavi d' Ercolano - No 3 - Marzo 1828'), p. 554 (7 Jul. 1828), 555 (25 Jul. 1828), p. 556 ('Giornale de’ R. scavi d'Ercolano - No 7 - Luglio 1828 ').

38 On the difficulty of identifying slave quarters in the Roman house see M. GEorge, "Servus and domus: the slave in the Roman house ", in R. Laurence, A. WallaceHadrill (dir.), Domestic space in the Roman world: Pompeii and beyond, Portsmouth RI, 1997, p. 15; S.R. Joshel, L.H. Petersen, The material life of Roman slaves, Cambridge, 2014, p. 4-6.

39 E. Cova, "Closets, Cupboards, and Shelves: Storage in the Roman House ", Phoenix 67.3-4 (2013), p. 376-382. 
street pavement. Each of the six rooms, with the exception of the northernmost room, is indicated on Bonucci's plan as having a narrow window in its west wall providing each with light, whilst the sections of the house by Bonucci and Zahn indicate that the rooms were covered by a roof pitched towards the garden ${ }^{40}$. Each had a doorway to the balcony at the north end of the east wall except for the most northerly room, where the doorway was at the south end of the east wall. The staircase from the floor below, in room 1, likely opened at the north end of the balcony with its head close to the doorway to the northernmost room although no opening is shown on Bonucci's plan of the upper floor. Worthy of note are also some significant differences between the drawings of Bonucci and Zahn regarding their depiction of the balcony (figs. 5-6). Zahn's elevation of the façade only illustrates the part of the balcony above the colonnaded entranceway, with the rest shown as a two-storey façade in which were a series of windows ${ }^{41}$. Moreover, Zahn's section depicts the staircase in room 1 rising into a narrow room above where on Bonucci's section the same space is part of the open and significantly wider balcony. At the head of Zahn's staircase is a doorway with a further northfacing doorway, drawn in section, with two steps down to the room situated above the north end of the portico ${ }^{42}$. These conflicting details aside, both Bonucci's elevation of the façade and section indicate that the balcony was unroofed, in the former for its entire length, and was fronted with a simple wooden diagonal cross fence, although no mention is made of this in the Giornale degli Scavi ${ }^{\mathbf{4}}$. However, the balcony's pavement was supported by the remains of wooden beams and appears to have been in opus signinum embellished with tesserae set in a diamond lattice pattern with pieces of coloured marble that created an impressive carpet for its entire length ${ }^{44}$. In terms of wall paintings, none are detailed in the excavation records although possible clues are provided by Bonucci and Zahn's sections. The latter represents the northernmost room as having simple field paintings of the same scheme as in the upper floor above the western wing of the large peristyle. In contrast, Bonucci's section indicates the socle and lower part of the main zone of a slightly different but similarly simple field scheme. Finally, it should be noted that Bonucci identified at least two of the rooms on this part of the upper floor as storerooms given their containing extensive food remains. These are identified in

\footnotetext{
40 A. Maiuri, Ercolano, p. 371.

41 W. Zahn, Die schönsten Ornamente und merkwürdigsten Gemälde, taf. 64.

42 W. ZAHN, Die schönsten Ornamente und merkwürdigsten Gemälde, taf. 65.

43 A. Maiuri, Ercolano, p. 363, fig. 294.

44 M. Ruggiero, Storia degli scavi di Ercolano, p. 557 (29 Sep. 1828), 557-558 (23 Oct. 1828), 562 (31 Oct. 1829: 'Ercolano 31 ottobre 1829. Giornale del R. scavo d'Ercolano. Ottobre 1829'), 559-560 ('Giornale del Real scavo di Ercolano dal mese di agosto fino a dicembre 1828 ').
} 
his 1835 publication of the excavations as ' 14 ' and ' 15 ' which on the accompanying plan of the upper floor labels with these numbers the fourth and fifth rooms, from south to north, facing the balcony ${ }^{45}$.

The northern end of the balcony was supported by at least three of the four columns and piers that fronted the street entrance directly below (figs. 3, 5-6, 8). This was situated at a slightly greater height than the southern part; a couple of steps, carried out in marble, dealt with the difference between the two. The remains of these were noted during the excavations and are shown on Bonucci's elevation of the house's façade ${ }^{46}$. The steps gave access to a wide corridor, which is shown on Bonucci's detailed plan of the upper floor as having an elaborate opus sectile pavement and orientated perpendicularly to the façade, turning a righthand turn at its west end (fig. 8) ${ }^{47}$. At this point a doorway provided access to a large L-shaped room, indicated as room '18' on Bonucci's plan of the upper floor. The detailed plan indicates a floor with mosaic pattern demarcating the transition from the previous corridor. It is uncertain whether this room is the same as that identified by Bonucci during the excavations as 'stanze N. i 27 ' although, if so,

45 C. Bonucci, Le due Sicilie, p. 40, fig. 12. M. Ruggiero, Storia degli scavi di Ercolano, p. 557 (29 Sep. 1828), 559 (25 Nov. 1828), 559-560 ('Giornale del Real scavo di Ercolano dal mese di agosto fino a dicembre 1828'). These rooms were identified by Bonucci (1835, p. 40, fig. 12) in his subsequent publication of the excavations although it is impossible to determine which finds came from which room. The finds from the first room were made on the $29^{\text {th }}$ of September 1828 and were initially described as having been in a single room. However, a later entry, summarizing the finds of the period between August and December 1828, implies they came from two different rooms, perhaps a simple error on Bonucci's part. The objects included two bronze bells, a bronze furniture fitting, bronze parts from a set of scales, a bronze lock, a fitting from a large door, a bronze ring from a piece of furniture, a marble herm, a small terracotta plate, a large quantity of beans, a deposit of grain and a wooden chest containing cake, perhaps made with honey, although the grounds on which this last identification were made are doubtful. In a neighbouring room was found a copper bowl. In another room described by Bonucci as a 'dispensa' and evidently the second of the two storerooms on this part of the upper floor were found late in November 1828 the carbonized remains of walnuts, dates, prunes and dried figs. A later entry, summarizing the finds between August to December, also notes the finding of a number of amphorae, a shelf with two terracotta lamps, a broken glass vessel and then further terracotta vessels that contained flour, grain, dough, condensed perfume, grass peas, lentils, garlic, conch shells and the remains of a basket or a strainer.

46 M. Ruggiero, Storia degli scavi di Ercolano, p. 558 (20 Nov. 1828). See also A. Maiuri, Ercolano, p. 371.

47 C. Bonucci, Le due Sicilie, fig. 12: 'Musaici del secondo piano della Magione d'Argo'. 


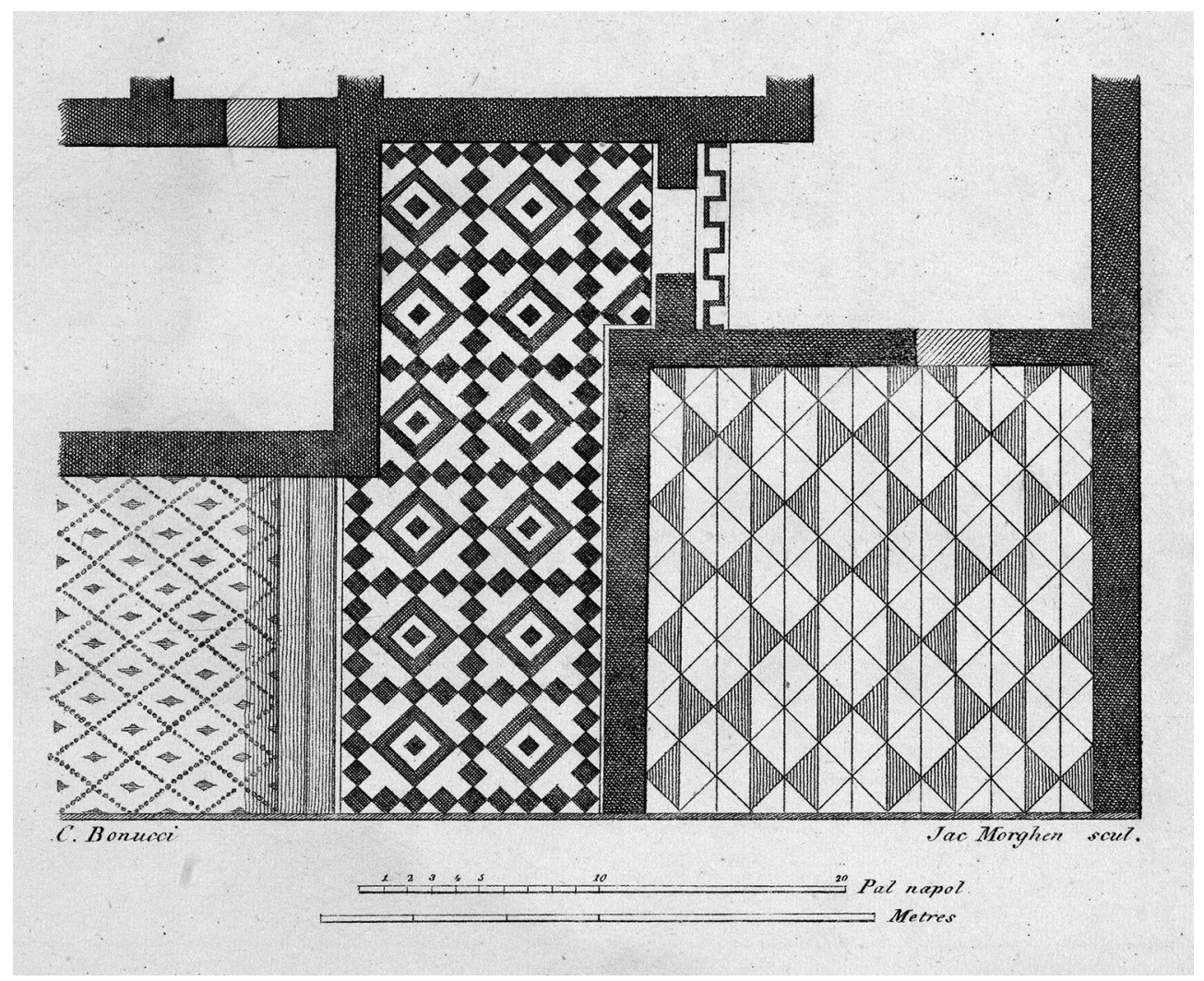

Fig. 8. Detail plan of the upper floor rooms of the Casa d'Argo above the street entrance by Bonucci (C. Bonucci 1835, fig. 12: 'Musaici del secondo piano della Magione d'Argo',

(C) British Library Board 7708.ee.36).

then the wall paintings were apparently of a fine quality ${ }^{48}$. In the east wall was a doorway to a square room the eastern part of which was situated on the north end of the balcony. This is labelled as room '17' on Bonucci's plan of the upper floor. According to Bonucci's detailed plan this room was paved with another lavish opus sectile design combining black and white triangles marble pieces, while his description of the room in late 1828, which refers to the flooring as being in mosaic, adds that the room was also decorated in paintings of good quality, although no specific details are given ${ }^{49}$. It is unclear, however, whether this was the same

48 M. Ruggiero, Storia degli scavi di Ercolano, p. 559-560 ('Giornale del Real scavo di Ercolano dal mese di agosto fino a dicembre 1828').

49 M. Ruggiero, Storia degli scavi di Ercolano, p. 558 (20 Nov. 1828), 559-560 ('Giornale del 
room, the previous room or even a room of the upper floor of the adjacent Casa del Genio (II, 2) ${ }^{50}$ that was described by Bonucci in late December 1829 as having paintings with small figures ${ }^{51}$. A subsequent entry at the end of the same month adds that the paintings also contained plants and animals while in the opposite wall of the same room was a niche that possibly served as a lararium, apparently without any plaster ${ }^{52}$. Bonucci later contradicted his initial description, indicating that the vault of the same feature was decorated with plaster covered reeds and with large panels with small twigs and flowers ${ }^{53}$. Maiuri ascribes these entries as relating to the Casa d'Argo ${ }^{54}$. One further detail of note, according to Bonucci, is that the upper floor room with the marble floor on the balcony was equipped with curtains ${ }^{55}$. There is no mention of these in the Giornale entries although the remains of curtain poles were also identified in the small peristyle ${ }^{56}$.

A final curious detail of the upper floor above this part of the house concerns the north end of the balcony supported by the columns and piers as the northernmost pier overlaps the façade of the Casa del Genio (II, 3). Both Bonucci's and Zahn's reconstructions of the façade indicate the extension of the balcony above the

Real scavo di Ercolano dal mese di agosto fino a dicembre 1828'), 562 (31 Oct. 1829: 'Ercolano 31 ottobre 1829. Giornale del R. scavo d'Ercolano. Ottobre 1829'); C. Bonucci, Le due Sicilie, p. 40. These paintings were presumably lost during the demolition of the upper floor as Bonucci gives no mention of them having been conserved.

50 On the excavation of the Casa del Genio, which followed that of the Casa d'Argo, see A. Maiuri, Ercolano, p. 375-376.

51 M. Ruggiero, Storia degli scavi di Ercolano, p. 563 (9 Dec. 1829).

52 Loc. cit. (31 Dec. 1829); C. Bonucci, « Ercolano », Bollettino dell'istituto di Corrispondenza Archeologica 1829, p. 196.

53 C. Bonucci, Le due Sicilie, p. 40.

54 A. Maiuri, Ercolano, p. 476, ft. 153, 477, ft. 182.

55 C. Bonucci, Le due Sicilie, p. 40. The curtains are also shown in Bonucci's reconstructive elevation of the façade (1835, fig 14). These curtains are unique in upper floor contexts at Pompeii and Herculaneum. However, there is potential evidence that lightweight partitions were also used on uper floor balconies. Iron nails associated with the remains of a balcony to the north of the Casa di Giulio Polibio (IX 13, 1-3) at Pompeii, led the excavators to conclude that these may have belonged to such a partition. See M. Oliva Auricchio et alii (dir.), La Casa di Giulio Polibio. vol. 2. Giornale di scavo 1966/1978, Pompei, 2001, p. 167 (15 May 1974), p. 169 (11 Jun. 1974), 170-171 (17-19 Jun. 1974), p. 273 ('schizzo n. 2'), p. 274-275 ('schizzo n. 6a-6b, 7).

56 On the curtain poles between the intercolumniations of the small peristyle see M. Ruggiero, Storia degli scavi di Ercolano, p. 545-546 (10 Mar. 1828), 549 ('Giornale de'Re scavi d'Ercolano - N. . 4-April 1828'), fig. 15; G. Bechi, « Iconografia e Ortografia dei nuovi Scavi di Ercolano ", Real museo Borbonico 7 (1831), p. 21, tav. LIX. 
neighbouring house as well, although as no connection to this is shown on Bonucci's plans of the upper floor it must be assumed that this part of the balcony belonged to and was accessed from the Casa del Genio ${ }^{57}$.

\section{Interpretations}

The upper floors of the Casa d'Argo are marked by their apparently different roles. The lavish decorations of the upper floor above the eastern side of the peristyle is in marked contrast with the more utilitarian spaces above the opposite portico, although here we are limited by our understanding of the unexcavated western zone of the house. There can be little doubt as to the quality of at least the floors in the rooms at the north end of the balcony overlooking the eastern façade. The opus sectile and mosaic floors in these rooms are the finest from any upper floor context at Pompeii or Herculaneum and are also the only examples of opus sectile known from an upper floor at either site. Mosaics from upper floors are also rarely attested at Pompeii although do appear in other houses at Herculaneum of varying type and so their apparent absence is rather more reflective of their preservation than any indication of their frequency in antiquity. The room at the northern end of the balcony was undoubtedly the most important in this part of the upper floor as is also suggested by the careful means of access to it and that it couldn't be viewed from the main part of the balcony to the south. In several other houses at Herculaneum we find rooms accessed from a balcony were often the largest and most important rooms on the upper floor, some most likely intended as dining spaces ${ }^{58}$. Dining necessitates service quarters and adequate storage space for provisions, for which there is evidence in the adjacent rooms here, and so dining could take place independently from the ground floor. Moreover, in none of the other balconies at Herculaneum can the occupants be shown to have been visible from the street as appears to be the case here. These rooms evidently served an important role in the social functioning of the house but this

57 Maiuri's later reconstruction of the balcony (1958, 366, fig. 296), drawn by R. Oliva, similarly shows the balcony extending above this northernmost pier with a room apparently equipped with glazed windows, although Maiuri neither mentions the reconstruction other than in reference, nor on which evidence it was based.

Examples of dining rooms accessed by means of a balcony can be identified in four 'independent' apartments (III, 12; IV, 3; V, 2 and V, 13-14) above the Casa del Tramezzo di Legno, the Casa dell'Alcova, the Casa Sannitica and the Casa del Bicentenario as well as on the upper floors of the Casa di Nettuno e Anfitrite (V, 6-7) and the Casa del Bel Cortile (V, 8). On upper floor balconies see J. N. Andrews, The use and development of upper floors in houses at Herculaneum, Ph.D. thesis, University of Reading, 2006, p. 75-85. 
appears to have been both potentially seasonal, given its exposed outlook, and also public in character. The staircase to the upper floor, located just inside the street entrance, was potentially accessible to visitors but was relatively isolated from the central areas of the house, suggesting that the upper floor was intended for guests. Indeed, Bonucci even suggests that the upper floor may have been for the viewing of public processions ${ }^{59}$. There is no evidence to support Bonucci's claim and such processions were, in any case, impossible in A.D. 79 given the ramp for Cardo III down to the shoreline was out of use ${ }^{60}$.

The character of the upper floor above the opposite wing of the large peristyle was distinctly utilitarian, comprising a cluster of small rooms whose function appears to be predominantly intended for food storage ${ }^{61}$. The known decorative remains of this part of the upper floor were of a basic type consisting of simple field schemes on a white background. Schemes of this kind appear in the upper floors of other houses at Herculaneum where they typically appear in less important rooms that were sometimes poorly lit $^{62}$. Domenico Esposito notes that at Pompeii such

59 M. Ruggiero, Storia degli scavi di Ercolano, p. 559-560 ('Giornale del Real scavo di Ercolano dal mese di agosto fino a dicembre 1828').

60 A. De Simone et alii, “ Ercolano 1992-1997 : la Villa dei Papiri e lo scavo della città », CErc 28 (1998), p. 28.

61 D. Esposito draws a parallel between the upper floors of the Casa d'Argo and those of the atrium complex of the Villa dei Papiri where grain and other foodstuffs have been discovered (D. Esposito, La pittura di Ercolano, Roma, 2014, p. 88). There are extensive food remains on upper floors at Herculaneum, which included purpose-built dry stores (J. N. Andrews, The use and development of upper floors in houses at Herculaneum, p. 87-92). Considered with the evidence from the Casa d'Argo gives reason to question Kastenmeier's (P. Kastenmeier, I luoghi del lavoro domestico nella casa pompeiana, Rome, 2007, p. 52) assertion that the inhabitants of Pompeian houses probably quickly consumed small quantities of perishable food given the apparent absence of food storage in the Pompeian archaeological record.

62 Useful examples can be seen in the Casa del Bel Cortile (V, 8) and in an apartment (V, 13-14) above the Casa del Bicentenario (V, 15-16). In the Casa del Bel Cortile two small rooms opening off the internal balcony were decorated in simple field paintings. The rest of the upper floor was comprised by two large dining rooms with mosaic floors, marble thresholds and impressive paintings of the Fourth Style in black and blue schemes. In the apartment of the Casa del Bicentenario the best-decorated rooms, which featured fine paintings of the Fourth Style, were situated in one corner of the apartment, accessed by means of a long balcony that extended above the house's façade. The rooms opening off the rest of the balcony, which included a latrine and a corridor in which was a painted lararium, and also three apparently unlit internal rooms were decorated in simple field paintings on a white ground. For further discussion see 
paintings are found in more modest housing or, in wealthier houses, in rooms of secondary importance ${ }^{63}$. Access to the different rooms was highly controlled here too; the storerooms equipped with an impressive range of doors and locks. Moreover, the range of rooms above the western wing of the large peristyle clearly formed a single complex, access to which was only possible through the corridor in the southeast corner of the upper floor gallery. The corridor and the small walling at the east end of the south gallery, on the north side, effectively presented both a physical and a visual barrier to individuals in the gallery; this suggests a deliberate attempt to marginalize those quarters, a trend identified by Andrew Wallace-Hadrill for elite Pompeian houses ${ }^{64}$. The closure of this end of the gallery may therefore imply something of the character of the rest of the upper floor to the west, although as only details of one room are known there is little ground on which to draw conclusions. The different nature of two upper floors in the house can also be seen in the use of architecture, particularly with respect to the character of the closed gallery above the small peristyle. We find similar upper floor galleries, closed but provided with windows to provide light, in other houses at Herculaneum ${ }^{65}$. These were mostly added during the ex novo rebuilding of those houses at various points in the first half of the $1^{\text {st }}$ century A.D., and given there is little evidence for similar galleries above peristylia at Pompeii might reflect a localized architectural trend and perhaps also common living practices. Besides providing a means of access to different rooms the galleries in the other houses at Herculaneum apparently served a diverse range of functions

J. N. ANDrews, The use and development of upper floors in houses at Herculaneum, p. 81, 82, 129, figs. 44-45, pls. 67-70 (Casa del Bel Cortile); p. 116-117, figs. 50, pls. 80-84 (Casa del Bicentenario).

63 D. Esposito, La pittura di Ercolano, p. 88. On the decorative schemes of these rooms see also V. M. Strocka, "Pompejanische Nebenzimmer », in B. Andreae, H. Kyrieleis (dir.), Neue Forschungen in Pompeji und den anderen vom Vesuvausbruch $79 \mathrm{n}$. Chr. Verschütteten Städten, Recklinghausen, p. 101-114; W. Енвнавdт, Dekorations- und Wohnkontext : Beseitigung, Restaurierung, Verschmelzung und Konservierung von Wandbemalungen in den kampanischen Antikenstätten, Wiesbaden, 2012.

64 A. Wallace-Hadrill, Houses and Society in Pompeii and Herculaneum, Princeton, 1994, p. 39-44. For subsequent discussion on the marginalization and control of access to slave quarters in Pompeian housing see also M. George, « Servus and domus: the slave in the Roman house "; P. Kastenmeier, I luoghi del lavoro domestico nella casa pompeiana, p. 10; S.R. Joshel, L.H. Petersen, The material life of Roman slaves, Cambridge, 2014, p. 78-84.

65 Houses at Herculaneum with closed upper floor galleries above peristylia: Casa dell'Atrio a Mosaico (IV, 1-2); Casa del Tramezzo di Legno (III, 4-12), Casa del Bicentenario (V, 1516), Casa del Salone Nero (VI, 11.13), Casa del Colonnato Tuscanico (VI, 17.26). 
including storage of building materials, dolia and amphorae, religious activity and even the safe storage of legal documents ${ }^{66}$. Visibility, or lack thereof, again appears to have been important. The walls of the galleries closed the upper level from the gaze of the invited visitor in the peristyle which might suggest that the upper floor needed to be out of sight from non-members of the household and so further reinforced the experience of privacy and enclosure from the outside ${ }^{67}$. The height of the galleries may have created issues with lighting on the floor below, exacerbated by the small size of their respective gardens and probably threw many of the adjacent ground floor rooms into shade even at midday. Some rooms probably never received direct sunlight, particularly during the winter, and were consequently dependent on light reflected off the walls of the upper floor. Such a situation has been postulated in the two-storey Hellenistic period Maison des comédiens at Delos ${ }^{68}$. Conversely, the rooms on the upper storey are more likely to have received more direct sunlight throughout the day and were potentially better lit in general.

We cannot consider light levels without also considering the resulting temperature that naturally varied on both a seasonal and daily basis. Those rooms receiving less sunlight on the ground floor would have been cooler than other areas of the house in summer, and possibly quite cold in winter, even in a relatively temperate climate such as that on the Bay of Naples. Conditions on the upper floor probably varied considerably too, particularly given the different nature of the two upper floors in the house. The open balcony overlooking the eastern façade appears suited to fair weather or fairer seasons while the upper floor above the eastern part of the house was both less exposed during inclement weather than the porticoes below but also, when sunny, would have benefitted from being in sunlight. The same principles may equally have applied on a daily basis. As a result of such fluctuating conditions there was, quite possibly, a distinctly seasonal use to the upper floors of the Casa d'Argo, as is substantiated by certain ancient writers.

66 On upper floor balconies in houses at Herculaneum see J. N. AndREws, The use and development of upper floors in houses at Herculaneum, p. 75-85.

67 On the social function of the peristyle see J.-A. Dickmann, "The peristyle and the transformation of domestic space in Hellenistic Pompeii », in R. Laurence, A. WallaceHadrill (dir.), Domestic space in the Roman world: Pompeii and beyond, Portsmouth RI, 1997, p. 121136; M. George, “ Repopulating the Roman house », in B. Rawson, P.Weaver (dir.), The Roman family in Italy: status, sentiment, space, Oxford, 1997, p. 310-311; E.W. LEACH, "Oecus on Ibycus: investigating the vocabulary of the Roman house ", in S.E. Bon, R. Jones (dir.), Sequence and space in Pompeii, Oxford, 1997, p. 59.

68 C. LöHr, "Griechische Häuser: Hof, Fenster, Türen nach 348 v. Chr. », in W.-D. Heilmeyer, W. Hoepfner (dir.), Licht und Architektur, Tübingen, 1990, p. 10-19. 
Vitruvius recommends the arrangement of seasonal rooms in the Roman house for this reason and there is no reason to suspect that his assertion did not extend to upper floors ${ }^{69}$. Moreover, Plutarch, in his treatise on cold temperatures paints a picture of living practices and upper floors specifically with respect to those of the Greek house in the Roman period where upper floors were used during the winter and the ground floor rooms during the summer ${ }^{70}$.

\section{Conclusion}

This brief review of the evidence for the architecture, decoration and fittings of the upper floors of the Casa d'Argo provides a valuable case-study for better understanding the complex role upper floors played in the Roman house, serving multi-functional and important social purposes. Unpicking the archival and historic records allows us to reconstruct in some detail the upper floors of one of Herculaneum's most important houses. This in turn highlights the singular achievements of the excavator, Carlo Bonucci, who not only carried out the first open-air excavation at Herculaneum, an immensely difficult task in itself, but who was also able to conduct a meticulous excavation that provided such an impressive wealth of finds and details about the upper floor of the house, especially when compared with contemporaneous works at Pompeii where structures and finds from upper stories were typically discarded as they were excavated. However, juxtaposed against this remarkable accomplishment was the inability to conserve their remains once excavated. The watercolours and drawings of Zahn provide a further and highly valuable source and allow us to corroborate many of the details provided by Bonucci.

Like other large houses at Pompeii and Herculaneum, the upper floors of the Casa d'Argo formed extensive quarters in their own right. We consequently find evidence for spatial specialisation, with the two upper floors serving distinct roles from one another; one both visible and accessible to the visitor and the other private in character being both invisible and far removed from the public parts of the house. The upper floor above the eastern wing of the large peristyle, overlooking Cardo III, contained a suite of cubicles, storerooms and highly decorated rooms at its north end which we can assume accommodated reception activity. Significantly, this activity was likely public in context, with the upper floor

69 Vitr., De arch. 6.4.1-2. The Greek house of the Hellenistic period, according to the literary sources at least, was also organised in such a way. See L.C. Nevetr, House and society in the ancient Greek world, Cambridge, 1999, p. 36.

70 Plut., De prim. frig. 20. The author is grateful for Evan Proudfoot (School of Archaeology, University of Oxford) for this reference. 
providing occupants with views of the street where they could both see and be seen and thereby also providing the owner with significant opportunities to reinforce social status. The presence of foodstuffs in at least one and possibly two adjacent storerooms provides an indication that dining could potentially have taken place separately from the ground floor, a feature characteristic of several other houses at Herculaneum. The upper floor above the western part of the house was capacious, apparently extending around three sides of the small peristyle and the western wing of the house, a number of rooms around the atrium complex as well as western portico of the large peristyle. Its character is in marked contrast to that above the eastern portico of the large peristyle. The upper floor gallery of the small peristyle was visually closed to visitors whilst the rooms above the western side of the large peristyle formed a closed complex given over to service, specifically including pantries for further storage of foodstuffs. Most of the documented decorative evidence in this zone is of simple white field schemes in the Fourth Style, although evidence for well-decorated spaces indicates that other parts of this upper floor may have served other roles. Yet usage is likely to have been more complex, particularly if we consider temporal or seasonal use. I have attempted to demonstrate that light and temperatures on the upper floor could also have been markedly different to those experienced on the ground floor and that both would have been highly changeable depending on the time of day or season. The open character of the upper floor above the eastern side of the house suggests it was poorly suited to inclement weather and better suited to summer or fair-weather use. Conversely, the upper floor gallery of the small peristyle was better protected from such extremes. In view of this, we have good reason to conclude that spatial use throughout the whole house was, in all likelihood, partly also seasonal and partly temporal and, far more complex than has been traditionally assumed.

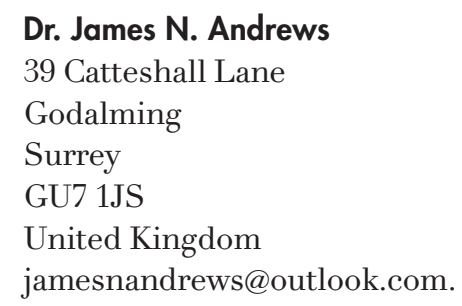


